\title{
PROFIL BERPIKIR SISWA SMA DALAM MENYELESAIKAN SOAL MATEMATIKA DITINJAU DARI KECERDASAN EMOSIONAL
}

\author{
Imtinan Dian Mudhiah \\ Pendidikan Matematika, Fakultas Matematika dan Ilmu Pengetahuan Alam, Universitas Negeri Surabaya \\ Email : imtinanmudhiah16030174088@mhs.unesa.ac.id \\ Siti Maghfirotun Amin \\ Pendidikan Matematika, Fakultas Matematika dan Ilmu Pengetahuan Alam, Universitas Negeri Surabaya \\ Email : sitiamin@unesa.ac.id
}

\begin{abstract}
Abstrak
Pada penyelesaian soal matematika, seorang individu memerlukan proses berpikir agar dapat memunculkan suatu ide untuk menyelesaikannya secara tepat. Tahapan berpikir berlangsung secara individual serta memiliki keterkaitan dengan interaksi sosial. Interaksi tersebut akan menghasilkan suatu perilaku, faktor yang memengaruhi perilaku adalah emosi. Agar perilaku yang dilakukan tidak berdampak buruk terhadap orang lain maka diperlukan kesiapan dan pemikiran. Pada uisa 12 tahun hingga 18 tahun seorang individu berada pada fase remaja. Jika seorang remaja merasa kegiatan sekolah tidak mampu menampung pemikirannya, maka akan diluapkan dalam tindakan yang kurang positif. Jadi sebaiknya remaja mempunyai kecerdasan emosional yang baik untuk mengontrol emosinya.

Penelitian ini merupakan penelitian deskriptif dengan pendekatan kualitatif yang bertujuan untuk mendeskripsikan bagaimana profil berpikir dalam menyelesaikan soal matematika berdasarkan tingkat kecerdasan emosional. Subjek dalam penelitian ini sebanyak tiga siswa yang terdiri atas satu siswa berkecerdasan emosional tinggi, satu siswa berkecerdasan emosional sedang, dan satu siswa berkecerdasan emosional rendah. Instrumen yang digunakan dalam penelitian ini yaitu angket kecerdasan emosional, tes penyelesaian soal matematika, dan wawancara terhadap tiga subjek tersebut.

Hasil penelitian menunjukkan bahwa siswa berkecerdasan emosional tinggi mampu menyelesaikan soal matematika materi SPLTV dengan benar, semua informasi pada soal digunakan, menulis langkah-langkah untuk menyelesaikan soal dengan runtut dan benar, memilih metode yang benar untuk menyelesaikan soal. Siswa berkecerdasan emosional sedang kurang mampu menyelesaikan soal matematika materi SPLTV dengan benar, karena terdapat informasi pada soal yang tidak digunakan, dan itu berakibat dalam memilih metode untuk menyelesaikan soal, sehingga dalam menyelesaikannya kurang benar. Siswa kecerdasan emosional rendah kurang mampu menyelesaikan soal matematika materi SPLTV dengan benar, karena kurang bisa mengingat pengetahuan yang dimiliki sebelumnya, terdapat informasi pada soal yang tidak digunakan, metode yang digunakan kurang benar, sehingga dalam menyelesaikannya kurang benar.
\end{abstract}

Kata Kunci: Berpikir, Soal Matematika dan Kecerdasan Emosional.

\section{Abstract}

In solving mathematical problems, an individual needs a thought process to come up with an idea to solve it appropriately. Stages of thinking take place individually and have a relationship with social interaction. The interaction will produce a behavior, the factors that influence the behavior are emotions. So that the behavior carried out does not have a negative impact on others, it requires readiness and thought. In 12 years to 18 years an individual depends on the adolescent phase. If a school that supports school activities cannot consider it, it will be overtaken in a less positive action. So teenagers should have good emotional intelligence to control their emotions.

This research is a descriptive study with a qualitative approach that aims to describe how the profile of thinking in solving mathematical problems based on the level of emotional intelligence. Subjects in this study were three students consisting of one student with high emotional intelligence, one student with moderate emotional intelligence, and one student with low emotional intelligence. The instruments used in this study were emotional intelligence questionnaires, mathematical problem solving tests, and interviews with these three subjects.

The results showed that students with high emotional intelligence were able to solve mathematical problems with SPLTV material correctly, all information on the questions was used, writing steps to solve problems coherently and correctly, choosing the correct method to solve the problems. Emotionally intelligent students are less able to solve mathematical problems with SPLTV material correctly, because 
there is information on questions that are not used, and that results in choosing a method to solve the problem so that in solving it is less correct. Low emotional intelligence students are less able to solve mathematical problems with SPLTV material correctly because they are not able to remember previous knowledge, there is information on questions that are not used, the methods used are not correct, so in solving them less correct. Keywords: Thinking, Mathematics, and Emotional Intelligence.

\section{PENDAHULUAN}

Matematika merupakan disiplin ilmu yang mendasari perkembangan teknologi modern saat ini. Dalam memelajari matematika seorang individu bukan hanya belajar mengenai cara berhitung saja akan tetapi belajar mengenai cara berpikir dalam menemukan dan memelajari pola maupun hubungan untuk menyelesaikan suatu soal matematika. Wibowo (2016) mengemukakan bahwa berpikir adalah suatu aktivitas yang akan menghasilkan suatu ide atau gagasan atau pemikiran yang akan diungkapkan secara lisan, tulisan, maupun isyarat.

Dalam menjawab soal matematika, seorang individu memerlukan proses berpikir. Dengan proses berpikir tersebut seorang individu akan memunculkan suatu ide dalam menyelesaikan soal matematika secara tepat. Pujiono (2017) memaparkan proses berpikir adalah serangkaian aktivitas mental dalam pikiran seseorang untuk menghadapi suatu informasi. Sigler dan saam (2010:104) "claims that thingking involves mental acst or events of one sort or another and that such events all depend on or are manifestation of particular sorts of brain activity", yang berarti berpikir melibatkan aktivitas mental yang bergantung pada aktivitas otak. Hakim (2014) menjelaskan dalam proses berpikir akan melibatkan empat tahapan, (1) menerima informasi, (2) mengolah informasi, (3) menyimpan informasi dan (4) memanggil kembali informasi.

Tahapan berpikir tersebut berlangsung secara individu. Berpikir memiliki keterkaitan dengan faktor lain, faktor lain tersebut yaitu lingkungan setempat, budaya setempat, dan interaksi sosial yang dilakukan. Dengan adanya interaksi tersebut seorang individu akan menghasilkan suatu perilaku. Prawitasari (1995) juga menjelaskan salah satu faktor yang memengaruhi perilaku adalah emosi. Dengan emosi seorang individu terangsang atau terdorong untuk memahami obyek yang akan mengubah perilaku tersebut, seperti rasa marah, rasa bahagia, rasa sedih, rasa cemas, rasa takut, rasa benci dan sebagainya.

Goleman (2000) menjelaskan emosi adalah serangkaian kecenderungan untuk bertindak dalam suatu kegiatan atau pergolakan pikiran, nafsu, kegiatan mental yang meluap dan perasaan. Dalam pengendalian emosi yang baik diperlukan adanya kesiapan dan pemikiran, agar perilaku yang dilakukan tidak berdampak buruk terhadap orang lain. Kesiapan dan pemikiran tersebut dapat ditinjau dari usia seorang individu. Pada uisa 12 tahun hingga 18 tahun seorang individu berada pada fase remaja. Pada usia tersebut seorang individu berada pada jenjang SMP atau SMA. Batubara (2010) memaparkan bahwa dalam tingkat perkembangan masa remaja tersebut, banyak mengalami perubahan seperti perubahan sistem kerja pada hormon dalam tubuh sehingga membawa perubahan psikis terutama emosi. Thridonanto (2010) menyatakan luapan emosi remaja yang tidak terarah sebaiknya dihindari, apalagi luapan emosi remaja tersebut dapat merugikan individu lain. Jadi remaja perlu memiliki kecerdasan emosional yang baik agar emosi yang ia keluarkan terkontrol.

Goleman (1998) menyatakan kecerdasan emosional adalah kemampuan lebih yang dimiliki seorang individu dalam mengendalikan emosi, ketahanan dalam menghadapi kegagalan, memotivasi diri, menunda kepuasan, serta megatur keadaan hati dan jiwa. Dengan adanya kecerdasan emosional tersebut berarti seorang individu dapat mengontrol emosi dalam bertindak. Kecerdasan emosional seorang individu memiliki beberapa komponen. Komponen tersebut dapat diukur menggunakan alat ukur kecerdasan emosional. Sejalan dengan pemaparan Goleman (2015) bahwa Emotional Intelligence (EI) terbagi ke dalam lima dimensi model kecerdasan emosioanal meliputi : (1) mengenali emosi diri (self awarness), (2) mengelola emosi diri sendiri (self control), (3) memotivasi diri sendiri (self motivation), (4) berempati (empathy), (5) membina hubungan dengan orang lain (social skill).

Hakim (2014) memaparkan bahwa kecerdasan emosional memiliki tiga tingakatan yaitu, kecerdasan emosional tinggi, sedang, dan rendah. Setiap tingkatan tersebut akan memiliki ciri-ciri yang berbeda-beda sesuai dengan kriteria masing-masing. Puspasari (dalam Hakim, 2014) mengemukakan bahwa seseorang dikatakan memiliki kecerdasan emosional tinggi, sedang, atau rendah memiliki beberapa ciri-ciri. Ciri-ciri individu memiliki kecerdasan emosional tinggi yaitu mampu mengendalikan emosi diri sendiri, mampu mengendalikan situasi yang memicu emosi, memikirkan akibat sebelum bertindak berdasarkan kondisi objektif yang ada, menyadari perasaan diri sendiri dan orang lain, dan dapat menyelesaikan konflik atau masalah yang dihadapinya dengan cara damai. Dengan itu, maka tingkat kecerdasan emosional yang tinggi akan memenuhi lima dimensi dalam kecerdasan emosional. Ciri-ciri individu memiliki kecerdasan 
emosional sedang yaitu mampu mengendalikan emosi diri sendiri tetapi didominasi pengaruh emosi yang dirasakan, terkadang sulit untuk mengendalikan situasi yang memicu emosi di luar batas yang dapat dikendalikan, kemampuan untuk menekan kondisi dari luar yang memicu emosi dirinya belum dapat dikendalikan, cenderung melakukan suatu hal secara tiba-tiba sesuai dengan hati, dan akan menenangkan emosi yang dirasakan sendiri. Dengan itu, maka tingkat kecerdasan emosional yang sedang akan memenuhi beberapa dari lima dimensi dalam kecerdasan emosional. Ciri-ciri individu memiliki kecerdasan emosional rendah yaitu lebih mengutamakan emosi yang dirasakan dibandingkan dengan apa yang dipikirkan, lebih melihat situasi berdasarkan apa yang dirasakan dibandingkan dengan kondisi yang akan dihadapi, lebih melihat segala sesuatu dengan nilai negatif, dan cenderung sering mengkritik, memberikan nasehat, serta memberikan perintah tanpa memperdulikan orang lain. Dengan itu, maka tingkat kecerdasan emosional yang rendah akan memenuhi beberapa dari lima dimensi dalam kecerdasan emosional.

Dari pemaparan di atas maka peneliti tertarik untuk meneliti tentang bagaimana Profil Berpikir Siswa SMA Dalam Menyelesaikan Soal Matematika Ditinjau Dari Tingkat Kecerdasan Emosional.

\section{METODE}

Jenis penelitian ini adalah penelitian deskriptif kualitatif. Penelitian deskriptif kualitatif ini dirancang untuk meneliti suatu subjek, suatu pemikiran, atau suatu peristiwa yang akan digambarkan secara deskripsi atau kalimat yang disusun cermat dan sistematis. Penelitian ini mendeskripsikan mengenai profil berpikir siswa SMA dalam menyelesaikan soal matematika ditinjau dari kecerdasan emosional. Penelitian ini memiliki 5 tahapan reancangan penelitan yaitu tahap persiapan, tahap pemilihan subjek, tahap pengumpulan data, tahap analisis data, dan tahap penyusunan laporan akhir.

Peneliti bertindak sebagai instrumen utama, sedangkan instrumen pendukung ada tiga yaitu, (1) angket kecerdasan emosional, yang digunakan untuk menentukan subjek penelitian yang akan diperoleh, (2) tes penyelesaian soal matematika dengan materi sistem persamaan linier tiga variabel (SPLTV), yang digunakan untuk memperoleh jawaban dari penyelesaian siswa sebagai dasar untuk mendeskripsikan profil berpikir siswa (3) wawancara, yang digunakan untuk menggali informasi lebih lengkap mengenai jawaban siswa pada saat tes penyelesaian soal matematika dari awal sampai akhir jawaban.

Data yang telah dikumpulkan dari ketiga instrumen tersebut dianalisis. Data hasil angket kecerdasan emosional dianalisis dengan menghitung skor total dari hasil pengisian angket kecerdasan emosional berdasarkan butir favorable dan unfavorable. Dari skor total tersebut diketahui tingkat kecerdasan emosional, rentang skor kecerdasan emosional tinggi adalah 184-250, rentang skor kecerdasan emosional sedang adalah 117-183, dan rentang skor kecerdasan emosional rendah adalah 50-116. Melalui angket tersebut peneliti mengelompokkan siswa berdasarkan tingkat kecerdasan emosionalnya yaitu tinggi, sedang, dan rendah. Kemudian dipilih satu siswa berkecerdasan emosional tinggi, satu siswa berkecerdasan emosional sedang, dan satu siswa berkecerdasan emosional rendah. Pada siswa berkecerdasan emosional tinggi dipilih siswa dengan skor tertinggi dari beberapa siswa yang memiliki kecerdasan emosional tinggi, pada siswa berkecerdasan emosional sedang dipilih siswa dengan skor tengah dari beberapa siswa yang memiliki kecerdasan emosional sedang dan pada siswa berkecerdasan emosional rendah dipilih siswa dengan skor terendah dari beberapa siswa yang memiliki kecerdasan emosional rendah. Penelitian yg relevan dengan penelitian ini yaitu (1) Arinda Uswatun Chasanah (2018) dalam penelitian yang berjudul "Profil Pemecahan Masalah Matematika Siswa SMP Ditinjau Dari Tingkat Kecerdasan Emosional", (2) Mariyana (2016) dalam penelitian yang berjudul "Profil Berpikir Siswa Kelas VII SMP Dalam Menyelesaikan Soal Cerita Aljabar Berpandu Pada Taksonomi Solo Ditinjau Dari Tingkat Motivasi Belajar Matematika", dan (3) Nor, dkk (2016) dalam penelitian yang berjudul "The Relationship Between Emotional Intelligence And Mathematical Competency Among Secondary School Students". Perbedaan penelitian ini dengan penelitian lain yaitu dari materi yang diambil yaitu SPLTV, subjek penelitian yang diambil yaitu siswa SMA serta tujuan penelitian yang akan dicapai.

Data hasil tes penyelesaian matematika dianalsis berdasarkan proses penyelesaian yang dilakukan oleh siswa secara bertahap. Langkah dalam menganalisisnya yaitu dengan mengkoreksi hasil tes penyelesaian soal matematika berdasarkan alternatif jawaban yang telah dibuat serta menyesuaikan hasil tes penyelesaian soal matematika berdasarkan indikator proses berpikir yang dicapai. Pada penelitian ini terdapat 10 indakator proses berpikir yang akan disajikan pada tabel berikut.

Tabel 1. Proses Berpikir Siswa Dalam Menyelesaikan Soal Matematika.

\begin{tabular}{|l|l|l|}
\hline No & \multicolumn{1}{|c|}{ Tahapan } & \multicolumn{1}{c|}{ Indikator } \\
\hline 1. & $\begin{array}{l}\text { Menerima } \\
\text { informasi }\end{array}$ & $\begin{array}{l}\text { Menjelaskan informasi yang } \\
\text { berkaitan dengan persoalan } \\
\text { SPLTV yang diberikan. }\end{array}$ \\
\cline { 3 - 3 } & & $\begin{array}{l}\text { Menuliskan informasi yang } \\
\text { diperoleh dari persoalan } \\
\text { SPLTV yang diberikan. }\end{array}$ \\
\hline 2. & & $\begin{array}{l}\text { Mengaitkan pengetahuan yang } \\
\text { dimiliki yaitu SPLDV, }\end{array}$ \\
\hline
\end{tabular}




\begin{tabular}{|c|c|c|}
\hline $\mathrm{No}$ & Tahapan & Indikator \\
\hline & \multirow[t]{2}{*}{$\begin{array}{l}\text { Mengolah } \\
\text { informasi }\end{array}$} & $\begin{array}{l}\text { keuntungan dan pajak dengan } \\
\text { informasi pada soal. }\end{array}$ \\
\hline & & $\begin{array}{l}\text { Merencanakan metode yang } \\
\text { digunakan yaitu eliminasi atau } \\
\text { substitusi atau keduanya dalam } \\
\text { mengerjakan soal. }\end{array}$ \\
\hline \multirow[t]{2}{*}{3.} & \multirow[t]{2}{*}{$\begin{array}{l}\text { Menyimpan } \\
\text { informasi }\end{array}$} & $\begin{array}{l}\text { Menyatakan rencana } \\
\text { penyelesaian yang akan dibuat. }\end{array}$ \\
\hline & & $\begin{array}{l}\text { Menuliskan langkah-langkah } \\
\text { penyelesaian soal dengan } \\
\text { rencana yang dibuat. }\end{array}$ \\
\hline \multirow[t]{4}{*}{4.} & \multirow[t]{4}{*}{$\begin{array}{l}\text { Memanggil } \\
\text { kembali } \\
\text { informasi. }\end{array}$} & $\begin{array}{l}\text { Mengingat pengetahuan yang } \\
\text { sudah dimiliki yaitu SPLDV, } \\
\text { keuntungan dan pajak dalam } \\
\text { membuat rencana. }\end{array}$ \\
\hline & & $\begin{array}{l}\text { Menggunakan informasi yang } \\
\text { telah dimiliki yaitu SPLDV, } \\
\text { keuntungan dan pajak dalam } \\
\text { menyelesaikan soal. }\end{array}$ \\
\hline & & $\begin{array}{l}\text { Mengingat kembali informasi } \\
\text { yang ada yaitu yang ditanya } \\
\text { dan diketahui untuk } \\
\text { menyelesaikan soal. }\end{array}$ \\
\hline & & $\begin{array}{l}\text { Menyimpulkan penyelesaian } \\
\text { soal dengan bahasa sendiri pada } \\
\text { informasi yang telah diketahui } \\
\text { dan ditanya pada soal. }\end{array}$ \\
\hline
\end{tabular}

Data hasil wawancara dianalisis dengan melakukan pengulangan hasil rekaman dan mencocokan dengan jawaban yang telah dikerjakan oleh siswa. Analisis dilakukan dalam tiga tahapan, yaitu, (1) reduksi data, (2) penyajian data, dan (3) penarikan kesimpulan.

\section{HASIL DAN PEMBAHASAN}

Berdasarkan hasil tes kecerdasan emosional dipilih tiga siswa yaitu 1 siswa berkecerdasan emosional tinggi, 1 siswa berkecerdasan emosional sedang, dan 1 siswa berkecerdasan emosional rendah.

Tabel 2. Tabel Skor Kecerdasan Emosional

\begin{tabular}{|c|c|c|c|}
\hline No & $\begin{array}{c}\text { Nama } \\
\text { Inisial }\end{array}$ & Skor & Kategori \\
\hline 1. & AV & 190 & Tinggi \\
\hline 2. & HF & 150 & Sedang \\
\hline 3. & TW & 113 & Rendah \\
\hline
\end{tabular}

Berdasarkan analisis hasil tes penyelesaian soal matematika yang dikaitkan dengan indikator proses berpikir siswa dan hasil wawancara. Berikut disajikan hasil tes penyelesaian soal matematika untuk setiap siswa berkecerdasan emosional tinggi, sedang, dan rendah.

\section{Hasil Tes Penyelesaian Soal Matematika Dengan} Subjek Kecerdasan Emosional Tinggi

Langkah awal yang dilakukan subjek berkecerdasan emosional tinggi. Dalam menerima informasi yaitu, membaca soal sebanyak dua kali pengulangan untuk memahaminya, dengan itu subjek dapat menceritakan kembali soal menggunakan bahasanya sendiri. Subjek juga dapat menjelaskan informasi yang terdapat pada soal secara jelas dan lengkap.Setelah subjek mengetahui informasi yang terdapat pada soal, subjek menuliskan yang diketahui dan yang ditanyakan secara runtut dan jelas pada lembar jawaban.

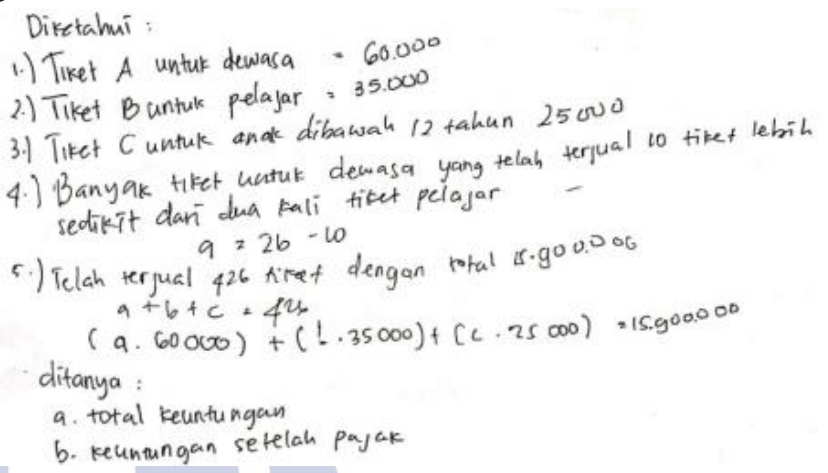

Gambar 1. Hasil Pengerjaan Tes Penyelesaian Soal Indikator IB

Dalam mengolah informasi, subjek dapat menjelaskan dan menunjukkan keterkaitan soal dengan materi yang telah dipelajari sebelumnya. Setelah mengetahui informasi dan mengaitkan soal dengan materi yang telah dipelajari yaitu SPLDV, keuntungan dan pajak, subjek memikirkan rencana awal yang akan dilakukan untuk menyelesaikan soal.

$$
\begin{aligned}
& \text { soal berkaitan dengan mater } \\
& \text { - SPLTY } \\
& \text { - SPKDY } \\
& \text { - Pajak Yeuntungan Yaritmatika sosial }
\end{aligned}
$$

Gambar 2. Hasil Pengerjaan Tes Penyelesaian

$$
\text { Soal Indikator } 2 \mathrm{~A}
$$

Dalam menyimpan informasi, subjek menjelaskan langkah-langkah untuk menyelesaikan soal, dan menuliskan secara runtut langkah-langkah tersebut pada lembar jawaban. Langkah-langkah tersebut sesuai dengan rencana awal yang telah dipikirkan sebelumnya. Metode atau cara yang digunakan subjek dalam menyelesaikan soal ialah metode substitusi dan eliminasi.

$$
\begin{aligned}
& \text { langkah langkah dalam pengerjaan } \\
& \text { - memisal kan } \\
& \text { - memodelkan ke dalam bentuk matematila } \\
& \text { - mengeliminasi dan mengsubtitusikan } \\
& \text { - menglutung harga keuntungan tiket } \\
& \text { - menpurlah total reuntungan } \\
& \text { - totald keunturgan dicar pajaknya }
\end{aligned}
$$

Gambar 3. Hasil Pengerjaan Tes Penyelesaian Soal Indikator 3B

Dalam memanggil kembali informasi, subjek telah menggunakan semua informasi yang terdapat pada soal 
dari yang diketahui, yang ditanyakan dan materi yang telah dipelajarinya yaitu SPLDV, keuntungan dan pajak. Subjek juga dapat menyimpulkan soal dari yang diketahui dan yang ditanyakan, serta subjek telah yakin bahwa penyelesaian yang telah dituliskan sudah benar dan memang benar.

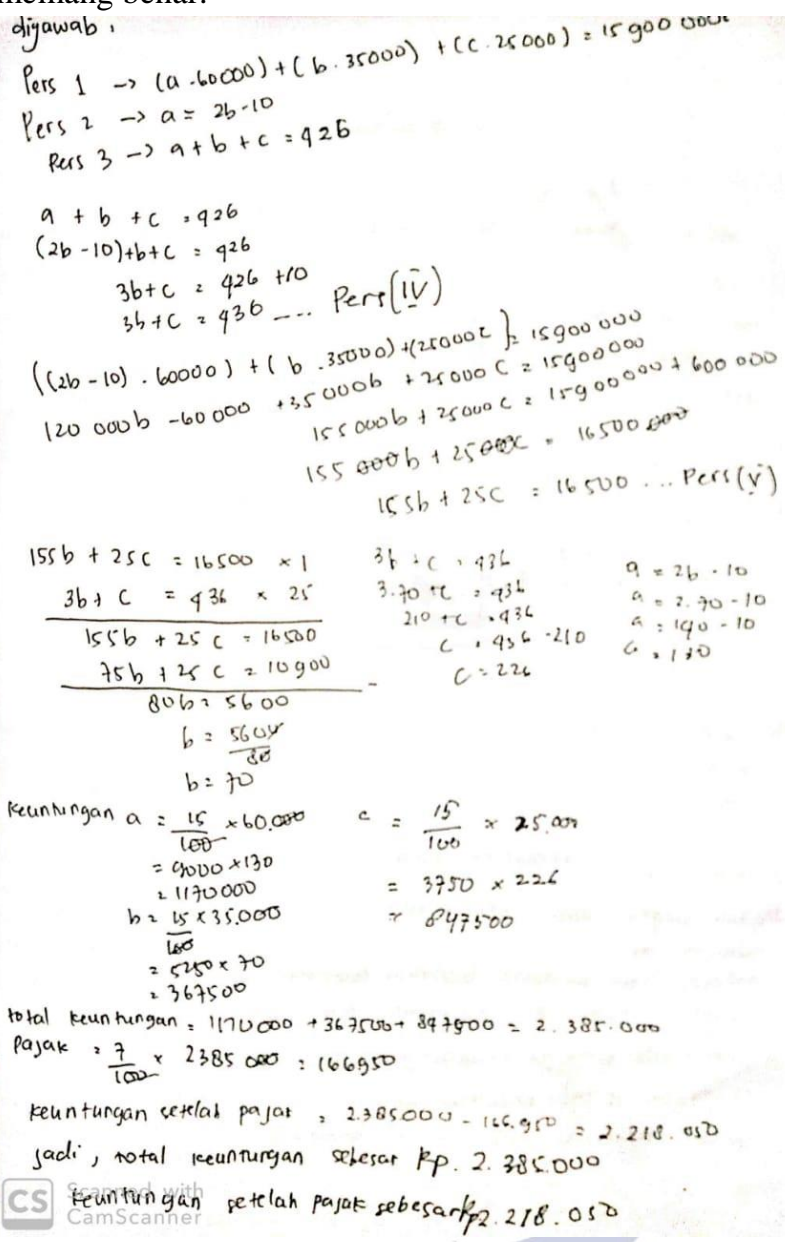

Gambar 4. Hasil Pengerjaan Tes Penyelesaian Soal Indikator 4B dan 4D

\section{Hasil Tes Penyelesaian Soal Matematika Dengan} Subjek Kecerdasan Emosional Sedang

Langkah awal yang dilakukan subjek berkecerdasan emosional sedang. Dalam menerima informasi, telah membaca soal sebanyak tiga kali untuk memahaminya, dengan itu subjek dapat menceritakan kembali soal, walaupun masih berpaku dengan kalimat yang terdapat pada soal. Subjek juga dapat menjelaskan informasi yang terdapat pada soal, kemudian setelah subjek mengetahui informasi yang terdapat pada soal, subjek menuliskan yang diketahui dan yang ditanyakan pada lembar jawaban. Pada saat menyebutkan yang diketahui subjek tidak menyebutkan semua informasi yang terdapat pada soal. Subjek langsung memodelkan dalam bentuk matematika pada penyelesaiannya. Seharusnya menyebutkan informasi yang sudah dimodelkan menjadi SPLTV dan SPLDV juga.

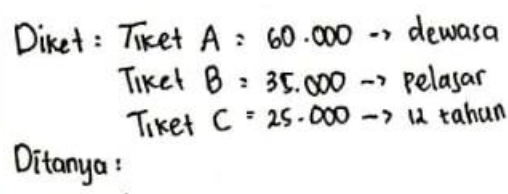

a. total keuntungan $15 \%$

b. Keuntungan setelah pajak $7 \%$

Gambar 5. Hasil Pengerjaan Tes Penyelesaian Soal Indikator IB

Dalam mengolah informasi, subjek dapat menjelaskan dan menunjukkan keterkaitan soal dengan materi yang telah dipelajari sebelumnya yaitu keuntungan dan pajak, walaupun tidak disebutkan secara menyeluruh seharusnya SPLDV, keuntungan dan pajak. Setelah mengetahui informasi dan mengaitkan soal dengan materi yang telah dipelajari, subjek memikirkan rencana awal yang akan dilakukan untuk menyelesaikan soal, walaupun rencana yang disampaikan kurang lengkap. Seharusnya kentungan, pajak dan SPLDV.

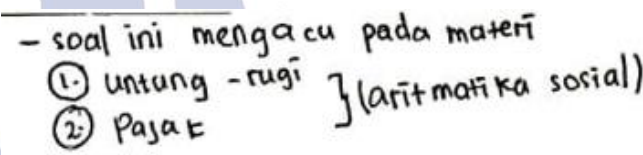

Gambar 6. Hasil Pengerjaan Tes Penyelesaian Soal Indikator $2 \mathrm{~A}$

Dalam menyimpan informasi, subjek menjelaskan langkah-langkah untuk menyelesaikan soal, dan menuliskan secara runtut langkah-langkah tersebut pada lembar jawaban. Langkah-langkah tersebut sesuai dengan rencana awal yang telah dipikirkan sebelumnya. Metode atau cara yang digunakan subjek dalam menyelesaikan soal ialah metode substitusi saja.

\section{- langkah - langkah}

(1.) mencari persamaan dulu

purikan persamaan yg berhubungan untuk mencari tiket yang tersual.

3.) dimasukfan dengan presentasi keuntungan untuk mencar total reuntungan

(4.) dikalikan presentasi pajak untuk men can hasil sth terkena pajak

Gambar 7. Hasil Pengerjaan Tes Penyelesaian

\section{Soal Indikator 3B}

Dalam memanggil kembali informasi, subjek belum menggunakan semua informasi yang terdapat pada soal dari yang diketahui, terdapat satu informasi yang tertinggal karena subjek terkecoh dengan soal. Pada yang ditanyakan dan materi yang telah dipelajari yaitu keuntungan dan pajak sudah digunakan. Subjek juga dapat menyimpulkan dari yang diketahui dan yang ditanyakan pada soal, akan tetapi subjek telah menyadari bahwa penyelesaian yang dituliskan kurang benar, jadi kesimpulan yang dibuatnya juga kurang benar. 


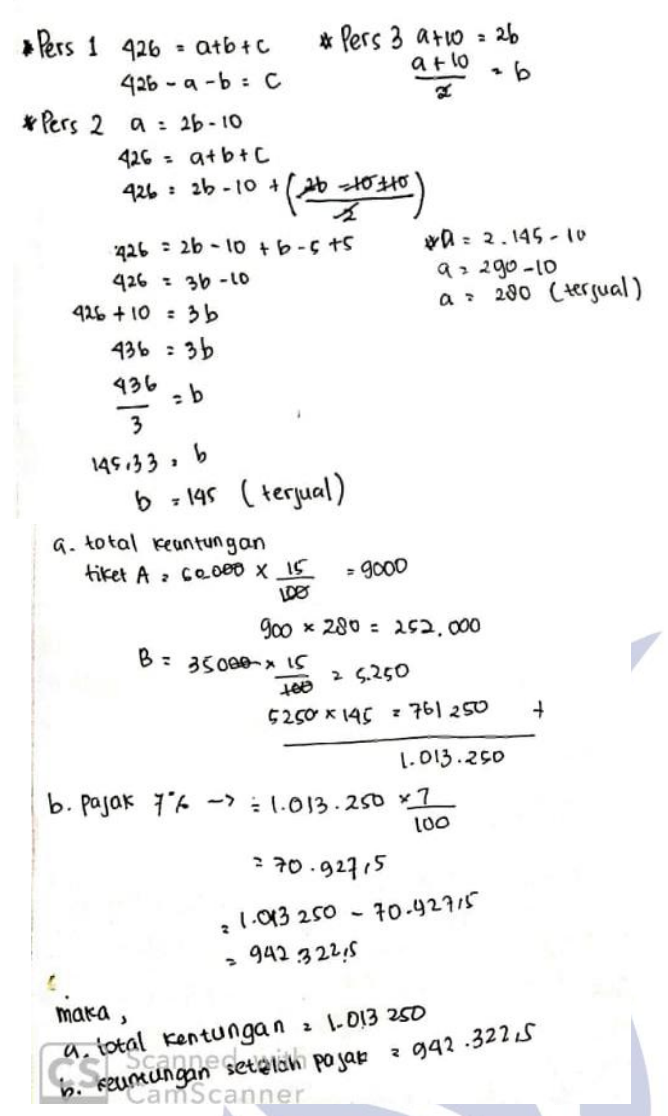

Gambar 8. Hasil Pengerjaan Tes Penyelesaian Soal Indikator 4B dan 4D

\section{Hasil Tes Penyelesaian Soal Matematika Dengan} Subjek Kecerdasan Emosional Rendah

Langkah awal yang dilakukan subjek berkecerdasan emosional rendah. Dalam menerima informasi, membaca soal sebanyak empat sampai lima kali pengulangan karena membutuhkan waktu yang lama dalam memahaminya. Dengan itu, subjek dapat menceritakan kembali soal walaupun masih membaca dan mengikuti kata-kata pada soal, tidak menggunakan bahasanya sendiri. Subjek juga dapat menjelaskan informasi yang terdapat pada soal, akan tetapi tidak lengkap, kemudian setelah subjek mengetahui informasi yang terdapat pada soal, subjek menuliskan pada lembar jawaban yaitu, yang diketahui dan yang ditanyakan, walaupun terdapat informasi yang tidak dituliskan dalam lembar jawaban.

$$
\begin{aligned}
& \text { Diket: Tlket } A \rightarrow \text { dewasa 60.000 (1) } A=60.000 \\
& \text { Tiket } B \rightarrow \text { pelajar 35.000 } \quad B=35.000 \\
& \text { Tiket } c \rightarrow \text { dibawah } 25.000 . \quad C=25.000 \\
& \text { Tiket terjual } 426 \rightarrow 15.900 .000 \\
& \text { Tiket } A \rightarrow \text { dewasa } \\
& \text { keuntungan } 15 \%
\end{aligned}
$$

Gambar 9. Hasil Pengerjaan Tes Penyelesaian Soal Indikator IB

Dalam mengolah informasi, subjek dapat menjelaskan dan menunjukkan keterkaitan soal dengan materi yang telah dipelajari sebelumnya yaitu SPLDV dan keuntungan, walaupun terdapat materi yang tidak dituliskan dalam lembar jawaban seharusnya SPLDV, keuntungan dan pajak. Setelah mengetahui informasi dan mengaitkan soal dengan materi yang telah dipelajari, subjek memikirkan rencana awal yang akan dilakukan untuk menyelesaikan soal, walaupun rencana yang disampaikan kurang lengkap. Seharusnya kentungan, pajak dan SPLDV.

$$
\begin{aligned}
& \text { - Dulupernah belajar sarcem persamaan linier, } \\
& \text { SPLDV gan tentzua keumhengan }
\end{aligned}
$$

Gambar 10. Hasil Pengerjaan Tes Penyelesaian Soal Indikator 2A

Dalam menyimpan informasi, subjek dapat menjelaskan langkah-langkah untuk menyelesaikan soal, akan tetapi tidak menuliskan langkah-langkah tersebut pada lembar jawaban, dan langkah-langkah tersebut sesuai dengan rencana awal yang telah dipikirkan sebelumnya. Metode atau cara yang digunakan subjek dalam menyelesaikan soal ialah metode substitusi saja.

Dalam memanggil kembali informasi, subjek belum menggunakan semua informasi yang terdapat pada soal. Dari yang diketahui, terdapat satu informasi yang tertinggal karena subjek sudah merasa kebingungan. pada yang ditanyakan dan materi yang telah dipelajari yaitu SPLDV dan keuntungan sudah digunakan. Subjek juga belum menyimpulkan dari yang diketahui dan yang ditanyakan pada soal karena waktu untuk mengerjakan sudah habis dan sudah kebingungan. Subjek tidak menyadari bahwa penyelesaian yang dilakukan kurang benar karena subjek sudah merasa kebingungan.

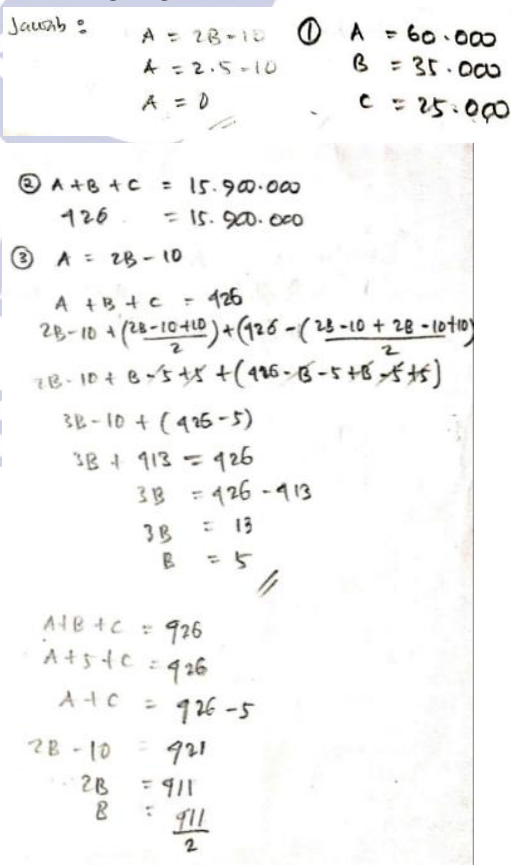

Gambar 11. Hasil Pengerjaan Tes Penyelesaian Soal Indikator 4B dan 4D 
Dari hasil di atas dapat dikatakan bahwa setiap siswa dengan tingkat kecerdasan berbeda memiliki proses berpikir yang juga berbeda.

Persamaan antara subjek kecerdasan emosional tinggi, subjek kecerdasan emosional sedang, dan subjek kecerdasan emosional rendah yaitu, dalam memanggil kembali informasi indikator mengingat pengetahuan yang sudah dimiliki dalam membuat rencana, ketiga subjek dapat melakukan dengan baik dan benar sesuai dengan pengetahuan yang diingat.

\section{Pembahasan}

Berdasarkan analisis yang telah dilakukan peneliti, pembahasan yang dapat dipaparkan ialah, proses berpikir subjek dengan tingkat kecerdasan emosional tinggi yang telah dijelaskan sebelumnya sejalan dengan hasil penelitian dari Chasanah (2018), yang menjelaskan bahwa subjek yang memiliki kecerdasan emosional tinggi dapat menjelaskan kembali soal menggunakan bahasanya sendiri, dapat menuliskan yang diketahui dan yang ditanya, dapat mengaitkan informasi soal dengan materi yang telah dipelajari, dapat memikirkan strategi untuk menyelesaikan soal, dapat menuliskan langkah-langkah secara runtut, dan yakin bahwa penyelesaian yang dilakukan benar karena telah diperiksa kembali. Wahyuni (2018) siswa dengan tingkat kecerdasan emosional tinggi dapat memahami soal, dapat menentukan rencana untuk menyelesaikan soal, dapat melakukan perhitungan dengan baik dan dapat menarik kesimpulan dengan baik.

Proses berpikir subjek dengan tingkat kecerdasan emosional sedang yang telah dijelaskan sebelumnya sejalan dengan hasil penelitian dari Izah (2018), yang menjelaskan bahwa subjek yang memiliki kecerdasan emosional sedang dalam menerima informasi subjek membaca soal terlebih, dengan membaca soal terlebih dahulu subjek dapat menyebutkan pertanyaan dalam soal dengan benar, namun tidak dapat menyebutkan dengan tepat yang diketahui pada soal. Subjek mengolah informasi dengan mengaitkan pengetahuan yang dimiliki dengan soal. Subjek menyimpan infomasi dengan menunjukkan penyelesaian yang akan digunakan untuk menyelesaikan soal. Subjek memanggil kembali informasi dengan menunjukkan dengan menjelaskan pemahamannya terhadap penyelesaian yang telah dia kerjakan, dan juga menuliskan kesimpulan akhir. Wahyuni (2018) siswa yang memiliki tingkat kecerdasan emosional sedang dapat memahami soal, dapat menentukan rencana dalam penyelesaiannya, kurang teliti dalam perhitungan untuk mendapatkan jawaban dari soal yang diberikan dan dapat menarik kesimpulan dengan baik.

Proses berpikir subjek dengan tingkat kecerdasan emosional rendah yang telah dijelaskan sebelumnya sejalan dengan hasil penelitian dari Chasanah (2018), yang menjelaskan bahwa subjek berkecerdasan emosional rendah kurang lengkap dalam penyelesaian soal dan tidak memeriksa kembali penyelesaiannya. Izah (2018) subjek menerima informasi subjek dengan kecerdasan emosional rendah membaca soal terlebih dahulu, dengan membaca soal terlebih dahulu subjek dapat menyebutkan pertanyaan dalam soal dengan benar, namun tidak dapat menyebutkan dengan tepat yang diketahui pada soal. Subjek mengolah informasi dengan mengaitkan pengetahuan yang dimiliki dengan soal, namun tidak menyebutkan dengan tepat. Subjek menyimpan informasi dengan menunjukkan penyelesaian yang akan digunakan untuk menyelesaikan soal, namun subjek tidak dapat menunjukkan dengan tepat. Subjek memanggil kembali informasi tidak dapat menjelaskan pemahamannya terhadap penyelesaiannya sendiri, Subjek tidak dapat menyebutkan dengan benar kesimpulan pada soal. Wahyuni (2018) siswa yang memiliki tingkat kecerdasan emosional rendah belum dapat memahami konteks soal dengan baik, dapat menentukan rencana untuk menyelesaikan soal, kurang teliti dalam perhitungan untuk mendapatkan jawaban dari soal yang diberikan dan belum dapat menarik kesimpulan dengan baik.

\section{PENUTUP}

\section{Simpulan}

Berdasarkan pemaparan analisis data dan pembahasan di atas, maka disumpulkan bahwa :

1. Siswa kecerdasan emosional tinggi dalam menyelesaikan soal matematika telah melakukan penyusunan ulang atau manipulasi kognitif dengan baik. Hal tersebut dilhat dalam proses menerima informasi ia dapat mengolah dan menafsirkan dengan menuliskan informasi yang diperoleh dengan jelas dan benar. Dalam mengolah informasi ia dapat mengaitkan informasi yang diterima pada persoalan SPLTV dengan pengetahuan yang dimiliki yaitu SPLDV, keuntungan, dan pajak. Dalam menyimpan informasi ia dapat menuliskan langkah-langkah penyelesaian soal dengan rencana yang dibuat dengan jelas, metode yang digunakan dalam mengerjakan soal dengan benar yaitu eliminasi dan substitusi. Dalam memanggil kembali informasi ia dapat menggunakan semua informasi pada persoalan SPLTV dan dapat menyimpulkan penyelesaian soal pada informasi yang telah diketahui dan ditanya pada persoalan SPLTV. Subjek telah mengecek kembali jawaban dan yakin bahwa jawaban yang ia tuliskan benar.

2. Siswa kecerdasan emosional sedang dalam menyelesaikan soal matematika kurang baik melakukan penyusunan ulang atau manipulasi kognitif. Hal tersebut dilhat dalam proses menerima informasi ia kurang dapat mengolah dan menafsirkan 
sehingga ia tidak lengkap dalam menuliskan yang diketahui dan ditanya. Dalam mengolah informasi ia kurang dapat mengaitkan informasi yang diterima pada persoalan SPLTV dengan pengetahuan yang dimiliki, hanya menyebutkan keuntungan dan pajak saja. Dalam menyimpan informasi ia kurang dapat menuliskan langkah-langkah penyelesaian soal dengan rencana yang dibuat, metode yang digunakan dalam mengerjakan soal hanya metode substitusi saja. Dalam memanggil kembali informasi ia tidak dapat menggunakan semua informasi pada persoalan SPLTV dan tidak dapat menyimpulkan penyelesaian soal pada informasi yang telah diketahui dan ditanya pada persoalan SPLTV. Subjek telah menyadari bahwa ia kurang teliti dalam pengerjaan soal sehingga penyelesaian yang dilakukan kurang benar.

3. Siswa kecerdasan emosional rendah kurang baik melakukan penyusunan ulang atau manipulasi kognitif. Hal tersebut dilhat dalam proses menerima informasi ia kurang dapat mengolah dan menafsirkan sehingga tidak lengkap dan kurang benar dalam menuliskan yang diketahui dan ditanya. Dalam mengolah informasi ia kurang dapat mengaitkan informasi yang diterima pada persoalan SPLTV dengan pengetahuan yang dimiliki, ia hanya menyebutkan SPLDV dan keuntungan saja. Dalam menyimpan informasi ia tidak dapat menuliskan langkah-langkah penyelesaian soal dengan rencana yang dibuat, metode yang digunakan dalam mengerjakan soal hanya metode substitusi saja. Dalam memanggil kembali informasi ia tidak dapat menggunakan semua informasi pada persoalan SPLTV dan tidak dapat menyimpulkan penyelesaian soal pada informasi yang telah diketahui dan ditanya pada persoalan SPLTV. Subjek tidak menyadari bahwa ia memberikan jawaban yang kurang benar, serta ia masih merasa kebingungan dalam memahami dan mengerjakan persoalan SPLTV tersebut.

\section{Saran}

Berdasarkan hasil penelitian yang telah diperoleh, saran yang dapat disampaikan sebagai berikut.

1. Guru dapat merancang pembelajaran yang dapat memfasilitasi siswa dalam mengembangkan kecerdasan emosional siswa. Pembelajaran yang disarankan adalah model pembelajaran kooperatif JIGSAW, dalam pembelajaran menggunakan model tersebut siswa dapat mengasah kemampuan bertanggung jawab, percaya diri, dan menghargai satu sama lain.

2. Guru dapat memberikan latihan soal yang beragam untuk meningkatkan kemampuan siswa dalam menyelesaikan soal SPLTV. Tidak hanya berpacu dengan materi SPLTV akan tetapi dapat dikaitkan dengan pengetahuan yang telah dipelajari sebelumnya, seperti SPLDV, aritmatika sosial, dan lainnya.

3. Hasil penelitian ini dapat dijadikan refrensi dan acuan untuk peneliti lain agar menjadikan penelitian yang serupa lebih baik lagi.

\section{DAFTAR PUSTAKA}

Batubara, Rl. J. (2010). "Perkembangan Remaja. Sari Pediatri” : Vol. 12, No. 1, 21-29.

Chasanah, A. U. (2018). "Profil Pemecahan Masalah Matematika Siswa SMP Ditinjau Dari Tingkat Kecerdasan Emosional”. Surabaya : Tidak dipublikasikan.

Goleman, D. (1998). "Emotional Intelligence : Mengapa EI lebih penting dari IQ”. Jakarta: Gramedia Pustaka Utama.

Goleman, D. (2000). "Emotional Intelligence : Mengapa EI lebih penting dari IQ”. Jakarta: Gramedia Pustaka Utama.

Goleman, D. (2015). "Emotional Intelligence : Mengapa EI Lebih Penting Dari IQ”. Jakarta: Gramedia Pustaka Utama.

Hakim, E. L. (2014). "Proses Berpikir Siswa SMP dalam menyelesaikan masalah matematika ditinjau dari perbedaan tingkat kecerdasan ekonomi dari gender". Disertasi tidak diterbitkan. Surabaya:Uiversitas Negeri Surabaya.

Izah, F. E. (2018). “Analisis Proses Berpikir Siswa Sma Dalam Menyelesaikan Soal Cerita Pada Materi Program Linear Ditinjau Dari Kecerdasan Emosional". Seminar Nasional Penelitian dan Pengabdian Masyarakat. LP4MP Universitas Islam Majapahit

Mariyana. (2016). "Profil Berpikir Siswa Kelas VII SMP Dalam Menyelesaikan Soal Cerita Aljabar Berpandu Pada Taksonomi Solo Ditinjau Dari Tingkat Motivasi Belajar Matematika”. AKSIOMA : 1-13.

Nor, Mohd, K., Ismail, Zaleha, dan Yusof, Mohammad, Y. (2016). "The Relationship Between Emotional Intelligence And Mathematical Competency Among Secondary School Students". Journal on Mathematics Education. Volume 7, No 2, 91-100.

Pujiono. (2017). "Proses Berpikir Siswa MA dalam Membuat Peta Konsep Turunan Ditinjau Dari Gaya Belajar Visual, Auditori, dan Kinestetik”. Tesis magister, tidak diterbitkan, UNESA.

Prawitasari, E. J. (1995). "Mengenal Emosi Melalui Komunikasi Nonverbal”. Buletin Psikologi : Tahun ke III nomor 1, 0854-7106. 
Sigler, Ellen A dan Saam, Julie. (2006). "Teacher Candidates Conceptual Understanding of Conceptual Learning”. Journal of Scholarship of Teaching and Learning. Vol. 6 (1). 118-126.

Thridhonanto, A. (2010). "Meraih Sukses dengan Kecerdasan Emosional". Jakarta: PT Elex Media Komputindo.
Wahyuni, S. (2018). "Deskripsi Kemampuan Menyelesaikan Soal Cerita Matematika Ditinjau Dari Kecerdasan Emosional Siswa Mts Negeri 1". Jurnal Pendidikan dan Pembelajaran Khatulistiwa.

Wibowo, K. A. (2016). "Defragmenting Struktur Berpikir Pseudo Dalam Memecahkan Masalah Matematika”. Yogyakarta:Deepublish.

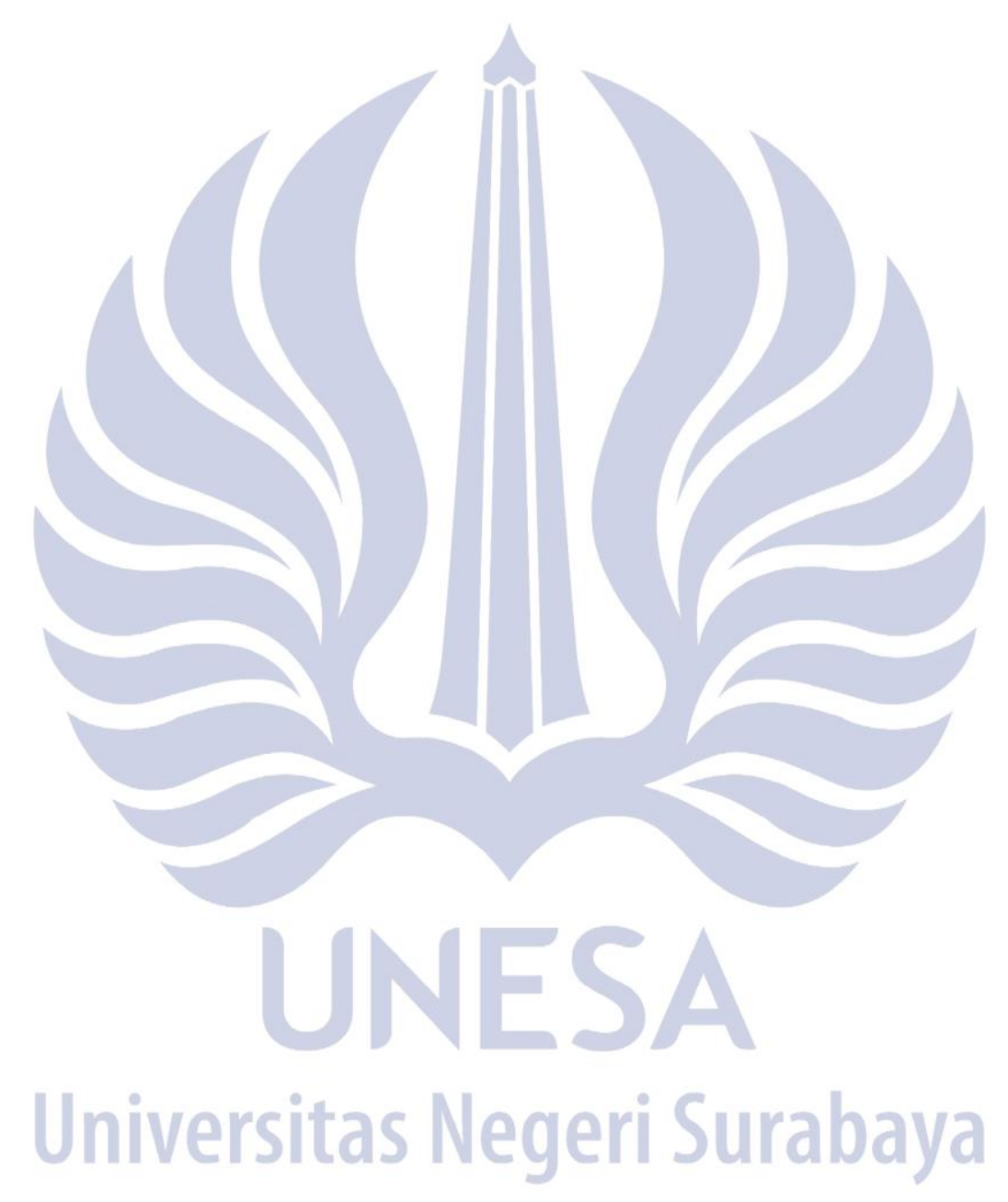

